University of Nebraska - Lincoln

DigitalCommons@University of Nebraska - Lincoln

Faculty Publications, Department of History

History, Department of

Summer 1989

\title{
"Would I Could Give You Help and Succour": Elizabeth I and the Politics of Touch
}

Carole Levin

University of Nebraska - Lincoln, clevin2@unl.edu

Follow this and additional works at: https://digitalcommons.unl.edu/historyfacpub

Part of the History Commons

Levin, Carole, "'Would I Could Give You Help and Succour": Elizabeth I and the Politics of Touch" (1989). Faculty Publications, Department of History. 68.

https://digitalcommons.unl.edu/historyfacpub/68

This Article is brought to you for free and open access by the History, Department of at DigitalCommons@University of Nebraska - Lincoln. It has been accepted for inclusion in Faculty Publications, Department of History by an authorized administrator of DigitalCommons@University of Nebraska - Lincoln. 


\title{
"Would I Could Give You Help and Succour": Elizabeth I and the Politics of Touch
}

\author{
Carole Levin
}

In 1462, in defense of the House of Lancaster, Sir John Fortescue wrote that Edward IV could not cure the king's evil, the disease scrofula, by touching the afflicted since to do so one must not only be a king but also a legitimate one. ${ }^{1}$ To touch one needed not only to be annointed with holy oil but the person must also be the legitimate heir. Lancastrians claimed that Edward IV could not touch since he was not the rightful king. Wrote Fortescue, he "wrongly claims to enjoy this wonderful privilege. Wrongly . . . [because] this unction is powerless because Edward had no right to receive it." Sir John goes on to argue by analogy, and scornfully asks: "Would a woman who received ordination thereby become a priest?"' 2 Of course not. Continuing this line of argument, Fortescue adds that a usurper would not be the only one unable to cure by touch.

Many duties likewise are incumbent on the kings of England in virtue of the kingly office, which are inconsistent with a woman's nature, and kings of England are endowed with certain powers by special grace from heaven, wherewith queens in the same country are not endowed. The kings of England by touch of their annointed hands they cleanse and cure those inflected with a certain disease, that is commonly called the King's Evil, though they be pronounced otherwise incurable. This gift is not bestowed on Queens. ${ }^{3}$

Yet less than a century later, queens of England were touching for the king's evil, and following other practices such as blessing metal for cramp rings (also used for healing) as well as conducting other religious services attached to Easter, such as washing the feet of the poor on Maundy Thursday. How did it happen that practices described as inappropriate and unworkable one century could be accomplished the next? What does this suggest about the nature of queenship and monarchy and its religious implications in the sixteenth century? This essay will explore and analyze responses to Mary and Elizabeth's

'The king's evil was the disease scrofula, a tubercular inflammation of the lymph glands of the neck. I am deeply grateful to Professor Clark Hulse and Professor Dennis Moore for their help when I began this project. Most of the research for this essay was accomplished when I was a Monticello Foundation Fellow at the Newberry Library, 1987 and I would like to express my appreciation to the Newberry Library for all their support. Professor Howard Solomon and Professor Retha Warnicke read this essay in draft. Their comments were most valuable. I would also like to thank Professor Elaine Kruse, Rozalyn Levin, Joseph Silvestri, and Beverly Behrman for their help in preparing this manuscript for publication.

${ }^{2}$ Marc Bloch, The Royal Touch: Sacred Monarchy and Scrofula in England and France, trans. by J. E. Anderson (London, 1973), p. 130.

${ }^{3}$ Raymond Crawfurd, The King's Evil (Oxford, 1911), p. 45. 


\section{Carole Levin}

popular religious practices in regard of the royal touch and the Maundy ceremony, and examine how these responses reflect the changing nature of monarchy in the sixteenth century.

Throughout medieval and early modern England there was a strong belief in magical healers, and the king was the most magical of all. ${ }^{4}$ Kings touched to cure the afflicted in England since the time of the saintly Edward the Confessor. After the Norman Conquest it seems that English kings saw the effect of the French people spontaneously going to their king to be cured and copied the measure as an effective means to gain religious-political support. Yet the practice seems to have waxed and waned in England in the Middle Ages. Despite Fortescue's concerns, there appears to have been relatively little touching for the king's evil by English kings in the fifteenth century, and we have no records of either Edward IV or Richard III touching, though Edward did have cramp rings made to distribute, which was another form of magical healing. 5 On Good Friday sovereigns went to the altar on their knees (known as creeping to the cross) and blessed metal in a dish by the altar. This metal was then fashioned into rings that were said to be particularly effective in the treatment of epilepsy and cramp, and especially of use for pregnant women. ${ }^{6}$

Henry VII, after a century or more of comparative neglect, restored the ceremony of the touch to all its dignity and established a full ceremonial, with a set office of service. ${ }^{7}$ Henry, whose claim to the throne by the right of primogeniture was extremely shaky, used a number of techniques to assure his prestige, including claiming his descent from the mythological King Arthur and producing a round table repainted in the Tudor colors of white and green which he claimed was the original round table. ${ }^{8}$ In the same way he named his

${ }^{4}$ Christina Larner, Witchcraft and Religion: the Politics of Popular Belief, Alan McFarlane, ed. (Oxford and New York, 1984), p. 148; Keith Thomas, Religion and the Decline of Magic (New York, 1971), pp. 192-200; Crawfurd, The King's Evil; Bloch, The Royal Touch; Walter Clifford Meller, "The King's Healing," in The Boy Bishop and Other Essays (London, 1923), pp. 81-94. Percy Ernst Schramm, A History of the English Coronation, trans. Leopold G. Wickham Legg (Oxford, 1937), pp. 125-26, W. Carew Hazlitt, Faiths and Folklores of the British Isles, A Descriptive and Historical Dictionary (1905, reprnt. New York, 1965), pp. 354-56

${ }^{5}$ The practice was popular in 15th century France. Louis XI touched for the Evil once a week, always after first going to confession (Crawfurd, The King's Evil, p. 48).

${ }^{6}$ Crawfurd, The King's Evil, p. 47; Bloch, The Royal Touch, pp. 92-107; Thomas, Religion and the Decline of Magic, pp. 198-99. Ives discusses how valued were cramp rings in the reign of Henry VIII. Eric W. Ives, Anne Boleyn (Oxford, 1986), p. 138. Many amulets were used in this period to try and protect a pregnancy. See Audrey Eccles, Obstetrics and Gynaecology in Tudor and Stuart England (Kent, Ohio, 1982), M. J. Tucker, "The Child as Beginning and End: Fifteenth and Sixteenth Century English Childhood,' in Lloyd DeMause, ed., The History of Childhood (New York, 1974), pp. 229-257, and Angus McLaren, Reproductive Rituals: The perception of fertility in England from the Sixteenth to the Nineteenth Century (London and New York, 1984). ${ }^{7}$ Thomas, Religion and the Decline of Magic, p. 193; Crawfurd, King's Evil, pp. 51-52.

${ }^{8}$ E. M. W. Tillyard, Some Mythical Elements in English Literature (London, 1961), pp. 46-52. See also, Carole Levin, "Most Christian King, Most British King: the Image of King Arthur in 
eldest son Arthur. Touching for the king's evil, something that could only be accomplished by the Lord's annointed, and which suggested the work of Christ himself, would be another means to assure his position. The touching became highly ritualized, and Henry VII gave each of the afflicted a gold angel as well as the king's healing touch.

Just as touching increased the monarch's prestige, so too did maintaining the practice of washing the feet of the poor on Maundy Thursday, the day before Good Friday and a time of year heavy with religious portent. ${ }^{9}$ By the Tudor period the monarch had become clearly associated with the Maundy ceremony. The ceremony of washing the feet of the poor done in imitation of Christ washing the feet of his disciples at the end of the Last Supper, was a part of the Easter vigil, and had been included in the church service for many centuries. In the Bible Christ told his disciples, "If I then, your Lord and Master, have washed your feet, ye also ought to wash one another's feet / For I have given you an example, that ye should do as I have done unto you.' 10

The Mandatum, or rite of the Washing of the Feet, was thus originally a simple act of charity very common in the Church. It became a liturgical rite sometime between the fifth and the seventh century. Its purpose was to express a sense of charity that should motivate the people who would be participating in the Lord's Supper during the time of high holiness of Easter. As a liturgical rite for Holy Thursday, we first find record of it in the canons of the 17th Synod of Toledo in Spain in 694. Evidently, however, the practice was even older, for the synod recommends its restoration. By the eleventh century the practice was being carried out in Rome. The Pope washed the feet of twelve subdeacons at the end of the evening Mass on Holy Thursday. When the other Holy Thursday rites were moved to the morning hours during the fourteenth century, the Mandatum remained a separate service to held in the afternoon. The ceremony of the Maundy was known in Britain by at least 600 . In the eighth century St. Alcuin set forth the correct way to celebrate it in his Book of Offices. ${ }^{11}$

Medieval monarchs also began to be involved in the Maundy. King John gave thirteen pence to each of thirteen poor men at the Maundy ceremony held

Tudor Propaganda," Avalon to Camelot, forthcoming.

${ }^{9}$ Brian Robinson, The Royal Maundy (London, 1977); Peter A. Wright, The Pictorial History of the Royal Maundy (London, 1981), Alexander Howard, Endless Cavalcade: A Diary of British Festivals and Customs (London, 1964), pp. 84-85; Christina Hole, British Folk Customs (London, 1976); Hazlitt, Faiths and Folklores of the British Isles, pp. 395-96 are useful on the topic of the monarchy's involvement in the Maundy. For a discussion of the Royal Maundy today, see Ilse Hayden, Symbol and Privilege: The Ritual Context of British Royalty (Tucson, 1987), pp. 18-20. ${ }^{10}$ Quoted in Robinson, The Royal Maundy, pp. 23-24.

"The New Catholic Encyclopedia (New York, 1967), 7: 105-07; 9: 146; Hole, British Folk Customs, p. 169. See also, William Charlton, "Maundy Thursday Observances: the Royal Maundy Money," Transactions of the Lancashire and Cheshire Antiquarian Society (1916): 201-19. 


\section{Carole Levin}

in Rochester in 1213. Apparently the thirteen represented the twelve apostles and either Christ or an angel who had visited the table of Pope Gregory the Great. But Edward II was the first English monarch to actually hold a Maundy himself. In the nineteenth year of his reign, Edward washed the feet of fifty poor men. ${ }^{12}$ Edward II may have extended the monarch's participation in the ceremony because he felt that he needed all the prestige he could get, given his political problems. Edward had already attempted to have the pope sanction a second coronation for him on the grounds that he had discovered some special holy oil given to St. Thomas à Becket by the Virgin Mary that should be used to anoint him. The pope, however, suggested if Edward wanted to use it to anoint himself privately he could go ahead; a second coronation was certainly not necessary. ${ }^{13}$ Edward may have felt an act in imitation of Christ himself to be a possible substitute.

The Maundy ceremony gradually developed. It became customary for the sovereign to provide a meal and to also give gifts of clothing, food, and money to the poor people involved. For example, in 1363 when Edward III was fifty years of age he provided for fifty of his subjects. By the age of the Tudors it had become so associated with the monarch that it came to be called the Royal Maundy. ${ }^{14}$ The idea of having the number of participants equal the age of the sovereign became institutionalized by the beginning of Henry VIII's reign. Each year Henry washed the feet of the number of men who equaled his age and gave each of the poor men whose feet he washed a red purse with the number of pence within it that also equaled his age. ${ }^{15}$ Roy Strong suggests that the medieval heritage of festival as a means to royal power was ecclesiastical, the prince in relation to the Holy Church. He mentions the Royal Maundy and the king's touch as examples of the greatest spectacles of medieval royalty. While the sixteenth century Tudors inherited such occasions, they were "extended and overlaid by what might be described as a liturgy of state," as the sixteenth century monarchy developed even more its symbolic significance. ${ }^{16}$

\footnotetext{
${ }^{12}$ Robinson, The Royal Maundy, p. 25.

${ }^{13}$ Bloch, The Royal Touch, pp. 137-38.

${ }^{14}$ Though others besides the king did it, including the Earl of Northumberland in 1511 and Cardinal Thomas Wolsey in 1530. Elizabeth of York and Catherine of Aragon both distributed money on Maundy Thursday. There is no evidence that they actually washed the feet of the poor (Robinson, The Royal Maundy, p. 26). Catherine of Aragon struggled over this issue after the divorce, since Henry decreed she could only hold a Maundy as princess dowager, not queen. This is discussed in a letter from Sir William Fitzwilliam, Treasurer of Henry VIII's Household to Thomas Cromwell (Henry Ellis, ed., Original Letters, Illustrative of English History, 2 vols. 2nd ed. (London, 1825), 2: 25-28).

${ }^{15}$ Robinson, The Royal Maundy, pp. 25-26.

${ }^{16}$ Roy Strong, Splendour at Court: Renaissance Spectacle and the Theater of Power (Boston, 1973), pp. 21-22. See also Roy Strong, Art and Power: Renaissance Festivals, 1450-1650 (Woodbridge, Suffolk, 1984), p. 19.
} 
The sixteenth and seventeenth centuries seem to have become the height of both ceremonies-touching and also blessing through the washing of the feet. ${ }^{17}$ Henry VII may well have believed this would increase his prestige as he further ritualized these practices, and his son Henry VIII continued them. Yet Henry VIII, who broke with the Catholic Church, seems to have been less interested in some of these rituals. As Raymond Crawfurd points out, apparently "the ceremonial of healing possessed no special sanctity and no exceptional importance in the mind of the 'Supreme Head of the Church." '18 Some ceremonies, such as the washing of the feet on Maundy Thursday and blessing cramp rings, continued in the reign of his son, others apparently did not. We have no record of Edward VI touching for the king's evil. One might perhaps wonder if this were due to his youth, but we have records of French kings touching as early as age nine. When Mary became queen in 1553, she continued and restored these ceremonies with great dignity as well as obvious personal feelings of piety. Elizabeth continued them as well. One reason that both the touching and the footwashing became so ritualized and performed with such high ceremonial is that these functions were part of a larger theatricalization of royalty using ritual to achieve and demonstrate power. By the sixteenth century, the monarch had become even more important symbolically; the image of the monarch, idealized as God's representative on earth, was a means to secure the people's allegiance. The Tudors, who ruled without a standing army or an extensive police force, had their power "constituted in theatrical celebrations of royal glory," in Stephen Greenblatt's words. For Elizabeth and Mary, as queens ruling instead of kings, this aspect of power through ritual and spectacle could be particularly important, though Elizabeth took much more advantage of it than Mary. Medieval monarchs did not make the claims of being God's lieutenant that began to emerge under Henry VIII. The position of the monarch and the nature of kingship emerges in the sixteenth century as an office so awe inspiring and powerful it could even encompass a female ruler, thus making it possible for her to perform religious acts-priestly acts-inconceivable for a fifteenth century woman. The idea of queenship was difficult for a people used to a monarch by definition male, but the change in the conception of monarchy, and the practices that went with this change, aided the English in accepting a woman ruler. ${ }^{19}$

\footnotetext{
${ }^{17}$ James II was probably the last monarch to perform the footwashing, though some historians claim that William III performed a modified version of the ritual. Though the ritual is still carried out today, after the end of the 17th century monarchs did not distribute their own gifts of money, food, and clothing until George V restored the custom in 1932. Elizabeth II distributes to both men and women, each group numbering her age. The last monarch to touch for the king's evil was Queen Anne.

${ }^{18}$ Crawfurd, King's Evil, p. 64.

${ }^{19}$ Stephen Greenblatt, "Invisible bullets: Renaissance authority and its subversion, Henry IV and Henry V,' in Political Shakespeare: New Essays in Cultural Materialism, Jonathan Dollimore and
} 
When Mary ascended the throne in $\mathbf{1 5 5 3}$ she was the first queen in her own right since the Conquest. The country considered the monarch as God's representative, and thus, by definition, male. Mary had to not only overcome her gender but the resistance to her determination to restore England to Roman Catholicism. It is hardly surprising that she eagerly embraced the rituals of healing and touch. In part as a way to quiet the reservations of many of her subjects on her accession, Mary also gave more in royal alms in 1553 than any year in the previous reign. ${ }^{20}$ There was not in Mary a desire to pursue these practices for propaganda reasons. A genuinely pious individual, Mary exacted less than the full public effect from these rituals.

After Mary's accession the newly restored Catholic Church made an effort to bring about a revival of many disused customs. Mary wrote to the Bishop of London in March, 1554 "that the laudable and honest ceremonies which were wont to be used, frequented and observed in the church, be also hereafter frequented, used, and observed." Cardinal Reginald Pole, the Archbishop of Canterbury, issued similar injunctions: "That all parishioners shall obediently use all the godly ceremonies of the church as (amongst therein enumerated) creeping to the cross."'21

For Mary, as a Catholic, the Easter season was an especially holy time. Mary continued the practice of washing the feet of the poor on Maundy Thursday. Mary's 1556 Maundy was commemorated with a painting on a table top by Nicholas Lizarde which, unfortunately, has not survived. ${ }^{22}$ There is also a reference to one of Mary's Maundies in Robert Fleetwood's Iterium ad Windsor. ${ }^{23}$ The day following Maundy Thursday, Good Friday, Mary blessed cramp rings. In the final Marian version of this ritual the curative value of the cramp rings is explicitly stated to have come from being rubbed in the royal hands, and the rings are valuable due to the supernatural qualities of the monarch, supporting the view of the monarch's own almost magical power in the

Alan Sinfield, eds. (Manchester, 1985), p. 44. For a discussion of this issue in general, see Stephen Orgel, The Illusion of Power: Political Theatre in the English Renaissance (Berkeley and Los Angeles, 1975), idem, "Making Greatness Familiar," The Power of Forms in the English Renaissance, Stephen Greenblatt, ed. (Norman, Okla., 1982), pp. 41-47, Leonard Tennenhouse, Power on Display: The Politics of Shakespeare's Genres (London and New York, 1986), Steven Mullaney, The Place of the Stage: Licence, Play, and Power in Renaissance England (Chicago and London, 1988), and the works already cited by Strong. Some sociologists, of the school of Emile Durkheim, argue in a positive theory of ritual that "religious beliefs and practices not only create and sustain the fundamental social structure of a society, but maintain the members' sense of reality"' (T. J. Scheff, Catharsis in Healing, Ritual, and Drama [Berkeley, 1979], p. 111).

${ }^{20}$ Robinson, The Royal Maundy, p. 16.

${ }^{21}$ Henry John Feasey, Ancient Holy Week Ceremonial (London, 1897), p. 127.

${ }^{22}$ Erna Auerback, Tudor Artists: A Study of Painters in the Royal Service and of Portraiture on Illuminated Documents from the Accession of Henry VIII to the Death of Elizabeth (London, 1954), p. 146.

${ }^{23}$ I am indebted to Professor Dennis Moore for this reference. 
sixteenth century. ${ }^{24}$ Mary also touched for the king's evil on Good Friday, traditionally a particularly holy day for this ritual. Mary, in her devotion, did not, however, fully exploit the potential publicity of the service.

The Venetian Ambassador, Marco Antionio Faitta, described Mary's 1556 Maundy and touching ceremony the next day on Good Friday. Accompanying Mary to the Maundy ceremony were Archbishop Pole, some other bishops, and her Council. Music was provided by the choristers of her chapel. Helping her in the ceremony were the Under Almoner, the Grand Almoner (the bishop of Chilchester), and her ladies in waiting and gentlewomen of the court. Faitta, who was at all the ceremonies, described them in great detail, paying especial attention to the role of the queen herself. "Her Majesty knelt down on both her knees before the first of the poor women, and taking in the left hand the woman's right foot, she washed it, . . . drying it very thoroughly with the towel which hung at her neck, and having signed it with the cross she kissed the foot so fervently that it seemed as if she were embracing something very precious." Mary did the like for each of the forty-one poor women, they being the same number as her age. "I vow to you that in all her movements and gestures, and by her manner, she seemed to act thus not merely out of ceremony, but from great feeling and devotion," Faitta wrote. After providing the women with food, alms, wine, cloth, shoes and stockings, a purse with fortyone pence, and the aprons and towels carried by her gentlewomen, Mary then left the hall to take off her gown, which was a very rich one of purple lined with fur. After a half hour she returned, and again examined all the women very carefully. Mary then gave the gown to the woman who looked the poorest and most aged, as was the custom with the Maundy robe. On Holy Thursday as well alms were distributed to three thousand people who thronged the court.

The next day on Good Friday Mary crept to the cross on her knees, blessed the cramp rings, and then withdrew from the service to bless those afflicted with scrofula.

But she chose to perform this act privately in a gallery where there were not above twenty persons. She caused one of the infirm women to be brought to her, when she knelt and pressed with her hands on the spot where the sore was. This she did to a man and three women. She then made the sick people come up to her again, and taking a gold coin-viz. an angel-she touched the place where the evil showed itself, signed it with the Cross and passed a ribbon through the hole which had been pierced in it, placing one of them round the neck of each of the patients, and making them promise never to part with that coin, save in case of extreme need.

Faita concluded his letter that "Having been present myself . . . at all these ceremonies, her Majesty struck me as affording a great and rare example of goodness, performing all those acts with such humility and love of religion, offering up her prayers to God with so great devotion and affection, and en-

${ }^{24}$ Thomas, Religion and the Decline of Magic, p. 199. 


\section{Carole Levin}

during for so long a while and so patiently so much fatigue; and seeing thus, that the more Her Majesty advances in the rule of this kingdom, so does she daily afford fresh and greater opportunities for commending her extreme piety.' 25 All of the ceremonies associated with the Easter Season, including touching for the king's evil, were clear demonstrations of Mary's piety if not her political pragmatism. Though deeply religious, Mary did not develop the full publicity for the monarchy with these rituals that she might have done.

Elizabeth was far more aware of how to use spectacle to enhance the prestige of the monarchy, which she did from the very beginning of her reign in her coronation ceremony. Yet the spectacle and public persona of monarchy was sometimes difficult for the queen. As Elizabeth herself said with some discomfort to a deputation of Lords and Commons in 1586, "We princes, I tell you, are set on stages, in the sight and view of all the world duly observed." 26 Thus, we know even more about Elizabeth's practices, and have a number of accounts of both her Maundy ceremonies and her touching for the king's evil. For Mary as a woman to continue these practices was already an unusual situation, but as a Catholic Mary wanted to re-establish practices that were not only royal but Roman. For Elizabeth, the situation was more difficult and complex. She was a woman ruler, a "female-king" who had also to balance the variety of demands on her for religious reform. Looking at what ceremonial she retained and what she let go gives us an insight not only into Elizabeth's religious sensibilities, but also a glimpse into the cultural attitudes of the English Renaissance toward religion and queenship. I believe the continuation of the Maundy ceremony and touching for the king's evil were another manifestation of the sacred aspect of monarchy Elizabeth represented to a people suffering from the dislocations of so many changes in church and state. She deliberately performed these ceremonies with as much drama as possible, a holy or sacred theatre, what Steven Mullaney calls "the theatrical apprehension of sovereign power.' 27 Her accession day celebrated as a "holy-day," 28 and the analogues with the Blessed Virgin Mary emphasized, blessing and curing with the queen's touch was yet another aspect of religious functions that were subsumed by the monarch. Some Catholics, however, would find this identification of Elizabeth as blasphemous, and as well for many Protestants these rituals and identification were examples of how Eliza beth had failed to truly purify the Church. Some Protestants explained

\footnotetext{
${ }^{25}$ Calendar of State Papers and Manuscripts Relating to English Affairs existing in the archives and collections of Venice and in other libraries of Northern Italy, Rawdon Brown, ed. (London, 1877), 6: 428-37 [Hereafter cited as CSP, Venetian].

${ }^{26} \mathrm{~J}$. E. Neale, Elizabeth I and Her Parliaments, 1584-1601 (London, 1957), p. 119.

${ }^{27}$ Mullaney, The Place of the Stage, p. 105.

${ }^{28}$ Strong, Art and Power, pp. 69-70.
} 
Elizabeth's touching as merely prayerful intervention to God, not a miraculous cure. Reginald Scot put it thus: "God will not be offended thereas for hir maiestie onelie useth godlie and divine praier, with some almes, and referreth the cure to God and to the physician."'29

The blessing of cramp rings did not extend into the reign of Elizabeth, and creeping to the cross was abandoned within a few years of her accession. Abandoning these practices may have been a concession to Protestants who perceived them as popish remnants. Elizabeth did, however, wash the feet of the poor on Maundy Thursday throughout her reign with elaborate ceremony that included, as had Mary's, drawing a cross on each foot as she finished. And touching for the king's evil became even more popular in her reign. Both her chaplain, William Tooker (1597), and her surgeon, William Clowes (1602), wrote books about scrofula and Elizabeth's remarkable talent for healing it through touch. It seems clear that Elizabeth chose to keep the ceremonies that were most public and had greatest value as spectacle and allow the less public ones to fall into disuse.

Elizabeth expressed herself eager to cure by touching throughout her reign. During Elizabeth's reign, instead of a fixed season for touching as had been done previously, occasions were arranged according to Elizabeth's inclinations, particularly when she felt a divine directive to do so or when she was strongly importuned by the applicants or their patrons. Sufferers would give their names to the royal Surgeons, who would examine each patient carefully to be sure the disease was really the Evil and there were no impostures. They would then submit a list to the queen who would appoint a day, usually a Friday, Sunday, or feast day. The ceremony often took place at St. Stephen's Chapel in the ancient palace of Westminster, though Elizabeth also touched to heal while on progress, thus not only presenting the ceremony through the mediating filter of her Court, but also demonstrating this prestige through the theatricalization of ritual in other parts of her kingdom.

William Tooker described how intensely she prayed to be able to transmit the healing touch. "How often have I seen her most serene Majesty, prostrate on her knees, body and soul rapt in prayer . . . how often have I seen her with her exquisite hands, whiter than whitest snow, boldly and without disgust, pressing their sores and ulcers, and handling them to health . . . how often have I seen her worn with fatigue, as when in one single day, she healed eight and thirty persons of the struma." 30 Tooker claimed that "most" of those touched eventually regained health. ${ }^{31}$ William Clowes also described in great

\footnotetext{
${ }^{29}$ Reginald Scot, The Discoverie of Witchcraft, with an introduction by Rev. Montague Summers (New York, 1972), p. 172.

${ }^{30}$ This is another term for scrofula.

${ }^{31}$ Crawfurd, The King's Evil, p. 75.
} 
detail specific cures Elizabeth had effected by touching when all other medical remedies had been tried and failed. ${ }^{32}$

Some specific instances when Elizabeth touched are known. While on progress at Kenilworth in $\mathbf{1 5 7 5}$ she not only knighted five gentleman but also "by her hignes accustumed mercy \& charitee, nyne cured of the penyfull and daugnerous diseaz, called the king's evill," wrote an eye witness Robert Laneham, who further explained in a private letter, "for that Kings and Queenz of this Realm, withoout oother medsin (save by handling and prayerz) only doo cure it." 33 Witnesses describe as well that Elizabeth actually touched the tumors and afflicted areas. We know at least later in her reign the ceremony was fixed and elaborate and presented in English rather than Latin. On August 18, 1596, a Venetian visitor observed the ceremony:

This year at the touching the Queen touched ten, and then washed her hands, being served by the Lord treasurer, the Lord Chancellor, and my Lord of Essex, all three on their knees; the treasurer in the middle, opposite the Queen holding a basin, the Chancellor on his right with a ewer of water, and on the left the Earl of Essex with a napkin which the Queen used to wipe her hands. ${ }^{34}$

Though clearly aware of the value of the theatricalization of holy ritual. Elizabeth did not touch simply for the propaganda value it afforded her. She apparently took the ceremony very seriously, and at times did not feel that at that specific moment she had the inspiration to cure by touching. At Gloucester, when throngs of the afflicted came to her for her aid, she had to deny them, telling them, "Would, would that I could give you help and succour. God, God is the best and greatest physician of all-you must pray to him." 35 It is possible that Elizabeth may have refused to touch because she was menstruating, which would have made her touch polluting. This may be also why Elizabeth did not touch in a fixed season, since this sometimes might have coincided with her periods, which were irregular. Popular culture in medieval and early modern England believed the touch of a menstruating woman could have disastrous effects on men, cows, gardens, bees, milk, wine, and much more, even if medical authorities of the time refuted it. ${ }^{36}$

\footnotetext{
${ }^{32}$ William Clowes, A right frutefull treatise for the artificiall cure of struma (London, 1602), pp. 49-50.

${ }^{33}$ Robert Laneham's Letter: Describing a Part of the Entertainment unto Queen Elizabeth at the Castle of Kenilworth in 1575, edited with an introduction by F. J. Furnivall (New York, 1907), p. 35.

${ }^{34}$ CSP Venetian, 9: 505 .

${ }^{35}$ Tooker gives this testimony, see Crawfurd, The King's Evil, pp. 75.

${ }^{36} \mathrm{~A}$ colleague, anthropologist Karin Andriolo, has suggested that Elizabeth may have refused to touch because she might have been menstruating (see Janice Delaney, Mary Jane Lupton, and Emily Toth, The Curse: A Cultural History of Menstruation [Urbana and Chicago, 1988], p. 42, and Eccles, Obstetrics and Gynaecology in Tudor and Stuart England, pp. 49-51). For nonWestern attitudes on menstruation, see Mary Douglas, Purity and Danger: An Analysis of Concepts of Pollution and Taboo (New York, 1966), pp. 147, 151, 176-77.
} 
The effectiveness of the queen's touch was a potent political force for her, and weapon against the ire of the pope. Indeed, the Protestant English feared the pope, whom Sir Walter Mildmay, for one, described as England's "most mortal and capital enemy." 37 They believed that each Maundy Thursday he pronounced a solemn anathema against all heretics and enemies. ${ }^{38}$ There was particular concern after the pope issued a bull of excommunication against Elizabeth in 1570. English Protestants publicly discounted the papal bull on the grounds that Elizabeth still had the God-given ability of a true monarch to cure by touch, and even English Catholics as well as Protestants continued to go to Elizabeth to be healed by her touch. ${ }^{39}$

As with touching, Elizabeth began celebrating the Maundy from the very beginning of her reign, and there are specific descriptions of a number of her Maundies, including 1560, 1565, 1572-73, and 1595. Lavina Teerlinc's New Year's gift of a miniature of Elizabeth performing this ceremony from the mid 1560 s provides even more information. The Hall where the Maundy took place was prepared with long tables on each side, set with all the paraphernalia needed for the ceremony. There were carpets and cushions on which the queen could kneel and basins of holy-water, alms, and other gifts for the recipients. The chaplain entered first, as did all the poor women who were to participate in the ceremony. There were the same number of women as years in the queen's age, thus the ceremony got longer as the queen grew older. These women would take their places, half on each side of the room. The Yeomen of the Laundry, with towels and a silver basin filled with warm waters and flowers, washed each women's feet and then wiped them. The women's feet were then washed by the Sub-Almoner and again by the Almoner.

After all this had taken place the queen then entered the hall and prayers and songs were sung in her honor. For these occasions Elizabeth dressed very formally, sometimes in blue, the color of the Virgin Mary, an identification which was often made for Elizabeth. Then the same number of ladies and gentlewomen as poor women addressed themselves with aprons and towels to wait upon the queen. Elizabeth, kneeling on the cushions, washed each woman's feet, and then kissed one, and then the other, after which she made on each foot the sign of the cross. After Elizabeth finished the foot washing itself, she gave each woman cloth for a dress, shoes, food, and wine. Then the aprons of each gentlewoman was given to the poor women. Each woman was also given a small white purse containing the number of pence of the queen's age.

In Maundy ceremonies of earlier reigns the monarch had usually given his robes to one of the recipients as the close of the ceremony, as Mary did with

\footnotetext{
${ }^{37}$ Cited in Neale, Elizabeth and Her Parliaments, p. 29.

${ }^{38}$ Charlton, "Maundy Thursday Observances," p. 205.

${ }^{39}$ Thomas, Religious and the Decline of Magic, p. 195; Crawfurd, The King's Evil, p. 70.
} 


\section{Carole Levin}

the 1556 Maundy. Elizabeth instead, so that she might keep her gown, ransomed it from the women by giving each recipient twenty shillings in addition to what they had already received. She did this to avoid choosing one person at the expense of the others. She may also have not wanted to part with the dress, given how Elizabeth felt about her clothes. Once the lengthy ceremony was completed Elizabeth took "her ease upon the cushion of state," still the center of attention, and there was more music. Finally, the ceremony being lengthy and by this time it being evening, the queen withdrew and the company departed.40

The emphasis on having the number of poor correspond to the monarch's age, as opposed to having twelve recipients as was usually the case, marks a major difference from other maundies, and places more emphasis on the specific monarch as Christ figure, rather than simply as an anonymous representative of the church. The fact that both Mary and Elizabeth performed the Maundy for women, as opposed to men, as earlier monarchs had done, would also emphasize their own gender.

Similar to the ceremony of touching, there was something courageous and unorthodox in a young, unmarried, Anglican woman taking on a function that was not only priestly, but an act in imitation of Christ himself. The horror over a woman's ordination, mentioned by Fortescue in the fifteenth century, was, if anything, even more potent a century later after the fears and dislocations of the Reformation, and was a view shared by many Protestants as well as Catholics. John Calvin wrote in his Institutes of the Christian Religion: "The practice before Augustine was born ... held that a woman was not allowed to speak in the church, and also not to teach, to baptise, or to offer. This was that she might not claim for herself the function of any man, much less that of a priest.... It is a mockery to give women the right to baptise." 41 Referring more specifically to queenship, John Knox wrote in 1558 , "By the Holy Ghost is manifestly expressed in these words, I suffer not a woman to usurp authority above the man. So both by God's law and the interpretation of the Holy Ghost, women are utterly forbidden to occupy the place of God in the offices 'foresaid, which he has assigned to man, whom he hath appointed to be his lieutenant on earth. The apostle taketh power from all women to speak in the assembly." 42 Though Knox aimed the first blast of his trumpet against the monstrous regiment of women at Mary I, he could not

\footnotetext{
${ }^{40}$ This description is taken from William Lambarde's eye witness account of Elizabeth's 1572-73 Maundy. John Nichols, The Progresses and Public Processions of Queen Elizabeth (London, 1823; new ed., 3 vols.; New York, n.d.), 2: 325-27.

${ }^{41}$ John Calvin, Institutes of the Christian Religion, John Baille, John T. McNeill, Henry P. Van Dusen, eds, trans. Ford Lewis Battles (Philadelphia, 1960), p. 1322.

${ }^{42}$ John Knox, The First Blast of the Trumpet Against the Monstrous Regimen of Women (Edinburgh, 1766), p. 22.
} 
deny when Protestant Elizabeth ascended the throne that these were still his sentiments. In the "apology" he sent Elizabeth he stated, "I can not deny the wreiting of a booke aganis the usurped Authoritie, and injust Regement of Women; neither [yit] am I myndit to retract or call back any principall point, or propositioun of the same, till treuth and verritie do farder appeir." 43 Yet Elizabeth's Maundy ceremonies, which might certainly be construed both to usurp the position of priest and also to retain popish practices, seem to have been highly regarded by many of the English; certainly she retained them throughout her reign, except when disease in London forbade such a public ceremony, and even then alms were widely distributed to make up for the loss of ceremony. ${ }^{44}$ In 1596 Elizabeth took the Maundy seriously enough to eliminate Bishop of London Fletcher from the ceremonial after he had offended her. In April of 1595 the records of Elizabeth's court stated that, "The Bishop of London that was to have had the place of the Queen's Almoner at the Maundy is now commanded not to deal it. It is said that both he himself and his wife have used insolent speeches and words to be wondered at concerning her Majesty." 45

The Maundy ceremony also gives us a unique opportunity to learn more about Elizabeth's own religious beliefs. Guzman de Silva wrote to Philip II on the 21 of April 1565 to describe Elizabeth's Maundy:

The Queen performed the customary ceremony on Holy Thursday. They tell me she did so with great dignity and devotion. . . . After she had washed the poor women's feet she deliberately traced a very large and well-defined cross and kissed it to the sorrow of many persons who witnessed it and of others who would not attend the ceremony, but to the joy of others.

Five days later de Silva reported to the king a conversation he had with Elizabeth about the ceremony.

I was praising lately to the Queen the ceremony she performed on Holy Thursday . . . and the devotion with which she made the crosses on the feet of the poor women and kissed them . . to to which she answered, "Many people think we are Turks or Moors here, whereas we only differ from other Catholics in things of small importance." 46

Both the Maundy and the ceremony of touch were so accepted by the English people throughout Elizabeth's long forty-five year reign that though James I

\footnotetext{
${ }^{43}$ John Knox, Works, David Laing, ed. (Edinburgh, 1895), 4: 366-67.

${ }^{44}$ March 23, 1564: "Proclamation remitting the distribution of the Maundy by the Queen in person, in the present time of contagious sickness, but alms will be given to the poor of Windsor and Eton." Calendar of State Papers, Domestic Series of the Reign of Edward VI, Mary, Elizabeth, and James I (London, 1865-72), 1: 236.

${ }^{45}$ Calendar of the Manuscripts of the Marquis of Salisbury (London, 1902), 5: 171 cited in G. B. Harrison, The Elizabethan Journals, 2 vols. (Ann Arbor, 1955), 2: 21.

${ }^{46}$ Calendar of the Letters and State Papers Relating to English Affairs Preserved in, or originally belonging to, the Archives of Simancas, ed. Martin Hume (London, 1899), 1: 419, 425 [hereafter cited as CSP, Spain].
} 


\section{Carole Levin}

did not want to continue the ceremony of touch when he ascended the English throne, his advisors convinced him it was crucial to do so for the loyalty it engendered. ${ }^{47}$ Both the ceremony of touch and the Royal Maundy continued throughout the seventeenth century.

By the sixteenth century the monarch's function was not only politicalreligious, but had also a special almost magical quality of the sacred in the minds of many of the people, a monarch who ruled by divine providence. In 1462 the thought of a woman performing such sacred functions as touching and blessing was perceived as not only blasphemous but ineffective. Yet by the end of Elizabeth's reign these functions were not only accepted but an important part of sacred monarchy whose physical body was female. As Mullaney points out, Elizabeth elided the vulnerability of power with the vulnerability of gender and turned both to her own advantage. ${ }^{48}$

Writing at the end of her reign, her surgeon William Clowes prayed for Elizabeth,
whose long life, much happines, peace and tranquility, let us all (according to our bounden dutyes) continually pray unto the Almighty God, that he will blesse, keepe and defend her Sacred person, from the malice of all her knowne and unknowne enemies, so that shee may forever raigne over us, (if it please the Lord God) even unto the ende of the world, still to cure and heale many thousands moe, then ever she hath yet done. ${ }^{49}$

Clowe's prayer, that Elizabeth might live and rule and cure until the end of the world, projects her not only into the sacred but beyond human into the divine. But we do need to take care how seriously we accept this prayer. In fact, Elizabeth in 1602 was a woman close to seventy years old, who especially after the Essex rebellion and its attack on both her person and her monarchy, was, in some people's eyes, clearly failing. And while imagery of the sacred was part of the way her people viewed Elizabeth, it was only one aspect of a multi-sided presentation; her gender and questions around her sexuality were also important parts of the way the English viewed their queen. ${ }^{50}$ Yet for at

\footnotetext{
${ }^{47}$ James had not touched while king of Scotland as the ceremony had never taken hold there. He may have performed a Maundy service, though it is doubtful since the Scots Presbyterians probably believed it too popish. His father, Henry Stuart, Lord Darnley, did perform a Maundy during the brief time he was king of Scotland after his marriage to Mary Stuart. De Silva mentions it in a letter of 29 April 1566 (CSP, Spain, 1: 546).

${ }^{48}$ Mullaney, The Place of the Stage, p. 105.

${ }^{49}$ Clowes, $A$ right frutefull treatise for the artificiall cure of struma, p. 50

${ }^{50}$ See Louis Montrose, "The Elizabethan Subject and the Spenserian Text," in Literary Theory/ Renaissance Texts, Patricia Parker and David Quilts, eds. (Baltimore, 1986), pp. 303-40, and "Shaping Fantasies: Figurations of Gender and Power in Elizabethan Culture," Representations 1, 2 (1983): 61-94. See also, Carole Levin, "Queens and Claimants: Political Insecurity in Sixteenth Century England,' in Gender, Ideology, and Action: Women's Public Lives in Historical Perspective, Janet Sharistanian, ed. (New York, 1986).
} 
Elizabeth I and the Politics of Touch 205

least some of her subjects, the discomfort they may have felt in seeing a woman rule and perform such actions had been lost in appreciation for all Elizabeth had done as a sacred monarch, one who both blessed and cured with a queen's touch. 